\title{
DESKRIPSI DAN PENYAJIAN TOKOH PADA WACANA BERITA KASUS e-KTP DALAM PERSPEKTIF PERS NASIONAL
}

\author{
Zamzani, Ahmad Wahyudin, dan Yayuk Eny Rahayu \\ Universitas Negeri Yogyakarta \\ email: zamzani@uny.ac.id
}

\begin{abstract}
(Title: Description and Presentation of Characters in The News in The Case of e-KTP in National Press Perspective). This study aims to describe the presentation of figures in the e-KTP case news discourse involving Setya Novanto. The research design used is a qualitative descriptive study with a critical discourse analysis perspective, especially the Fairclough model. The data source of this research is the news about the e-KTP case involving Setya Novanto in Kompas, Republika, and Media Indonesia. The data collection technique was done by observing and taking notes. The validity of the data used in this study was content validity and pragmatic semantics. The reliability of this study uses an interrater and discussions with peers. Based on the results of the analysis, several things were found related to the description of the characters in the e-KTP case. The representation of the identity of the actors in the e-KTP case is presented in different ways in each media. In these three media, only Republika tends to be more detailed and complete in representing the character (the identity of the perpetrator). The depiction of identity begins with the mention of the perpetrator's name, position, wife, children, nephews, and religion. Kompas puts more emphasis on facts relating to the perpetrators. Not everything related to the perpetrator is revealed. Meanwhile, Media Indonesia is more focused on the involvement of other actors.
\end{abstract}

Keywords: the e-KTP case, Setya Novanto, national press perspective.

\section{PENDAHULUAN}

Wacana dalam sebuah teks berita selalu berhubungan dengan media massa. Berbagai macam teks berita digunakan untuk merepresentasikan ideologi mereka. Hal ini menunjukkan bahwa media massa digunakan sebagai sarana penyebaran ideologi penguasa, sebagai alat untuk mengesahkan berbagai macam kejadian, dan sebagai kontrol terhadap wacana publik. Berkaitan dengan ideologi media, Shoemaker dan Reese (1996 : 23) menjelaskan "media reflect the ideology of those finance them, or "pay the piper." Oleh karena itu, untuk berbagai macam keperluan, media massa dengan skala nasional sering kali menampilkan pemberitaan yang menjadi berita utama mereka. Kasus yang sama dapat dikemas dengan berita yang berbeda. Hal itu terjadi karena setiap media massa mempunyai aturan dan ideologi yang berbeda. Republika, Kompas, dan Media Indonesia dikenal sebagai media yang selalu menyajikan berbagai sudut pandang yang berbeda. Pers nasional digunakan sebagai agen konstruksi sosial untuk menggiring opini publik sesuai dengan kepentingannya. Media massa apapun baik nasional maupun lokal merupakan alat bagi kelompok-kelompok tertentu untuk mempengaruhi atau melegitimasi berbagai macam kepentingan.

Produksi berita dalam surat kabar sangat berhubungan dengan latar belakang penulisnya, bahkan latar belakang surat kabar tersebut, karena wartawan (penulis) tentu harus mewakili ideologi surat kabarnya. Penulisan berita tentu bukan tanpa rencana. Misalnya, berita yang berkaitan dengan kasus korupsi, ada banyak latar yang dapat diambil wartawan untuk penguatan atau pemfokusan berita. Latar belakang pelaku korupsi, latar belakang penyidik (KPK) sebagai badan pengusut kasus korupsi, atau tuntutan dari segi hukum yang sedang terjerat kasus korupsi menjadi bahan pertimbangan penulisan sebuah berita. Masingmasing topik akan dipaparkan sesuai dengan visi dan misi surat kabar. Keberpihakan surat kabar menjadi hal utama dalam menguraikan 
pemaparanberita, sehinggamampumembangun opini publik, sesuai dengan kerangka pikir dan ideologi media.

Paradigma wacana kritis dapat digunakan untuk menganalisis media massa sebagai sebuah entitas yang bebas nilai. Studi wacana kritis merupakan salah satu studi yang berkembang pesat dan menarik perhatian para ahli linguistik. Dalam hal ini, kajian tentang analisis wacana telah melampaui pakempakem linguistik konvensional, wacana tidak lagi dipandang sebagai organisasi bahasa di atas kalimat sehingga wacana hanya berkutat dengan teks dan talk, namun telah melibatkan faktor-faktor sosio-politis dan ideologis. Dengan demikian, pada perkembangan berikutnya telah bermunculan beragam kajian yang terkait dengan analisis wacana, misalnya melihat hubungan wacana dengan ideologi masyarakat, hubungan wacana dengan politik dan sebagainya, yang kemudian dikenal dengan analisis wacana kritis.

Wacana sendiri merupakan rangkaian ujar atau rangkaian tindak tutur yang mengungkapkan suatu hal (subjek) yang disajikan secara teratur, sistematis, dalam suatu kesatuan yang koheren, dibentuk oleh unsur segmental maupun nonsegmental bahasa (Alex, 2004). Menurut Fowler (via setiawan, 2014: 112) memberikan pandangan yang berbeda, di mana wacana adalah tuturan atau tulisan yang dilihat dari sudut pandang kepercayaan (cara pandang terhadap dunia atau ideologi yang dianut), nilai dan berbagai kategori yang melingkupinya. Jadi, wacana adalah proses komunikasi, yang menggunakan simbol-simbol, yang berkaitan dengan interpretasi dan peristiwa-peristiwa di dalam sistem kemasyarakatan yang luas. Wacana akan selalu berhubungan dengan ideologi dan nilainilai yang dianut masyarakat. Analisis wacana terkadang mengarah ke ranah sosial politik yang sangat dekat dengan masyarakat luas. Meskipun pada awalnya kajian analisis wacana hanya bertujuan untuk mendeskripsikan penggunaan bahasa, atau untuk apa bahasa itu dipakai (Brown, 1983).

Fairclough (1992: 63) menjelaskan bahwa penggunaan wacana menunjuk pada pemakaian bahasa sebagai praktik sosial lebih daripada praktik individu sehingga menghasilkan sejumlah implikasi. Ia membagi wacana menjadi tiga dimensi, yaitu 1) text, 2) discourse practice, dan 3) sociocultural practice. Text dianalisis secara linguistik dengan cara melihat kosakata, semantik, dan tata kalimat. Selain itu, aspek kohesi dan koherensi yang terdapat dalam kalimat juga menjadi perhatian.

Analisis teks secara linguistik digunakan untuk melihat tiga masalah sebagai berikut. Pertama, ideasional yang merujuk pada representasi tertentu yang akan ditampilkan dalam teks (ideologi). Analisis pada tataran ini melihat bagaimana suatu hal (ideologi) ditampilkan dalam teks. Kedua, relasi merujuk pada hubungan antara penulis dengan pembaca dan situasi penyampaian teks. Ketiga, identitas merujuk pada konstruksi tertentu dari identitas penulis dan pembaca dan bagaimana personal dan identitas ini ditampilkan.

Discourse practice merupakan dimensi yang berhubungan dengan proses produksi dan konsumsi teks. Dalam dimensi ini, penafsiran sebuah teks didasarkan pada aspek produksi teks, penyebaran teks, dan penggunaan teks. Pada tahap produksi teks, analisis dilakukan untuk melihat pihak-pihak yang terlibat dalam produksi teks itu sendiri (siapa yang mempoduksi). Analisis dapat dilakukan pada tataran terkecil hingga terbesar (pemilik modal). Analisis penyebaran teks digunakan untuk mengetahui media apa yang digunakan untuk menyebarkan teks tersebut. Perbedaan media yang menyebarkan akan memberikan dampak yang berbeda pula. Analisis konsumsi teks digunakan untuk mengetahui pihak-pihak yang menjadi konsumen atau pembaca teks tersebut.

Sociocultural practice merupakan analisis tingkat makro yang berhubungan dengan konteks di luar teks. Konteks dalam hal ini dapat mencakup konteks situasi yang berhubungan dengan masyarakat atau budaya dan politik tertentu. Tataran analisis pada bagian ini meliputi aspek situasional, institusional, dan sosial. Analisis pada tataran situasional dilakukan dengan melihat 
konteks peristiwa yang terjadi pada saat teks diproduksi. Analisis pada tataran institusional dilakukan untuk melihat bagaimana pengaruh institusi (pembuat teks) ketika memproduksi teks. Biasanya, institusi atau pembuat teks mempunyai kekuatan untuk mempengaruhi isi dari sebuah teks. Analisis sosial digunakan untuk melihat aspek mikro, seperti ekonomi, politik, sosial dan budaya masayarakat secara keseluruhan.

Berdasarkan penjelasan di atas, melalui analisis wacana kritis, kita dapat mengetahui isi teks hingga mendalam. Teks hadir dengan membawa ideologi tertentu yang dititipkan oleh penulisnya agar orang yang membaca teks tersebut mengikuti apa yang diinginkannya. Berdasarkan uraian pada latar belakang, fokus permasalahan penelitian adalah analisis wacana kritis berita Setya Novanto dalam wacana berita daring. Deskripsi ideologi teks berita dan keberpihakannya akan terdeskripsi dalam deskripsi aktor dan ketelibatan aktor dalam sajian beritanya. Adapun rumusan masalahnya adalah bagaimana representasi aktor lain pada kasus Setya Novanto dalam perspektif pers nasional.

\section{METODE}

Rancangan penelitian yang digunakan adalah penelitian deskriptif kualitatif dengan perspektif analisis wacana kritis, khususnya model Fairclough (1992 :58). Hal ini di dasrkan pertimbangan bahwa wacana berita sarat dengan idiologi yang ingin disampaikan oleh media. Untuk mengunkapkan ideologi tersebut, diperlukan analisis secara interpretatif, reseptif, sekaligus sosial. Untuk itulah, ancangan aanalisis wacana kritis dipandang mampu mengungkapkan makna wacana baik dari dimensi teks, kewanaan maupun dimensi sosialnya.

Secara operasional penelitian ini mendeskripsikan proses analisis wacana kritis dengan fokus analisis aktor yang muncul dalan teks pemberitaan kasus korupsi yang menjerat Setya Novanto. Sumber datanya diambil dari tiga surat kabar daring, yaitu Kompas, Republika, dan Media Indonesia. Ketiga surat kabar daring ini dianggap mewakili pers dengan skala nasional karena dianggap memiliki ideologi yang berbeda. Pengambilan data dilakukan pada saat Setya Novanto berstatus tersangka, yaitu pada tanggal 17 Juli 2017 sampai dengan vonis Setya Novanto pada 24 April 2018. Adapun data yang dianalisis terdiri dari 20 topik dari 48 judul berita.

Teknik pengumpulan data dilakukan dengan teknik simak dan catat. Adapun langkahlangkahnya adalah sebagai berikut: 1) membaca dengan cermat surat kabar yang menjadi sumber data, 2) mengidentifikasi bentuk-bentuk tuturan sekaligus mengidentifikasi kata kunci yang sesuai dengan tema berita, 3) menyusun datadata tersebut dalam kartu data untuk dilakukan kategorisasi, 4) kategorisasi data berdasarkan tema dan pokok bahasan 5) melakukan analisis dengan ancangan analisis wacana kritis dan pandan pragmatis. Langkah analisis data dilakukan dengan cara; mengidentifikasi data berdasarkan permasalahan, dilanjutkan dengan proses tabulasi dan dijelaskan secara deskriptif kualitatif. Interpretasi dilakukan dengan memperhatikan pada fokus permasalahan. Data-data yang ada akan ditafsirkan dan diintrepretasikan, baik dari dimensi dimensi teks, wacana maupun dimensi sosial budaya.

Validitas dan reabilitas sangat diperlukan dalam penelitian ini, agar data terjaga validitasnya. Adapun validitas data yang digunakan dalam penelitian ini adalah validitas isi dan semantik pragmatik. Validitas isi dinilai mampu mengungkapkan konsepkonsep yang hendak diukur, yaitu aspek tekstual tentang berita Setya Novanto di media massa. Sementara itu, validitas semantik dan pragmatik digunakan untuk menafsirkan data dengan mempertimbangkan maknakeseluruhan untuk mengetahui aspek kewacanaan dan sosiobudaya. Sementaraitu, reabilitas penelitian ini menggunakan intrarater dan diskusi dengan teman sejawat. Diskusi dengan teman sejawat dilakukan untuk pengecekan keakuratan hasil identifikasi dan interpretasi data.

\section{HASIL DAN PEMBAHASAN}

\section{Representasi Identitas Pelaku Kasus Setya Novanto dalam Perspektif Pers Nasional}

Kajian analisis wacana kritis dengan menggunakan teori Norman Fairclough menitikberatkan pada hubungan teks (mikro) 
dengan konteks sosial masyarakat (makro). Kajian teks pada tataran mikro menitikberatkan pada tiga aspek, yaitu representasi, relasi, dan identitas. Pada tahap representasi akan terlihat bagaimana penggambaran pelaku atau peristiwa di dalam teks, tahap relasi akan terlihat bagaimana hubungan antara penulis berita, khalayak, dan partisipan di dalam teks, dan tahap identitas akan terlihat identitas wartawan, khalayak, dan partisipan berita digambarkan di dalam teks. Sementara itu, kajian wacana kritis pada tataran makro menitikberatkan hubungan antara teks dengan sosiobudaya yang melingkupinya.

Representasi identitas dalam hal ini berhubungan dengan penggambaran pelaku kasus e-KTP, Setya Novanto. Penggambaran identitas dimulai dari penyebutan nama pelaku, jabatan, istri, anak, keponakan, dan agama. Sama seperti halnya penelitian yang dilakukan oleh Mardikantoro dan Santoso (2017) yang menyatakan bahwa media melalui pemberitaannya cenderung mengarah pada gerakan menolak dan mengecam adanya kasus korupsi. Melalui penggambaran identitas tersebut sebenarnya media tidak mau menutup-nutupi kasus korupsi e-KTP. Berikut ini penggambaran pelaku kasus e-KTP yang melibatkan Setya Novanto oleh media Republika, Kompas, dan Media Indonesia.

\section{Representasi Nama Pelaku}

Terdapat beberapa kesamaan dan perbedaan penggambaran identitas yang dilakukan oleh Republika, Kompas, dan Media Indonesia. Berikut ini representasi identitas nama pelaku kasus E-KTP pada tiga media tersebut.

Bagan 1. Representasi Nama Pelaku pada Tiga Media

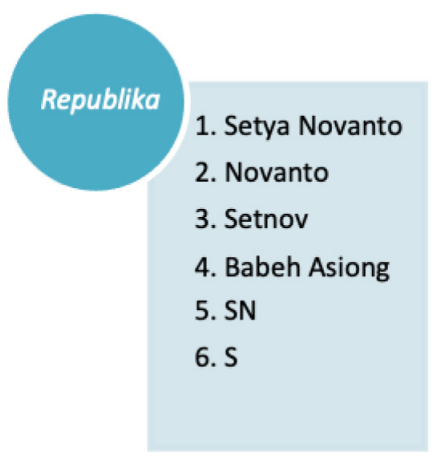

Bagan di atas menunjukkan bahwa ketiga media nasional memiliki persamaan dan perbedaan dalam merepresentasikan nama pelaku. Republika, Kompas, dan Media Indonesia menyebutkan nama pelaku dengan sebutan yang sama, yaitu 1) Setya Novanto dan 2) Novanto.

(1) Sebelumnya, pengadilan tindak pidana korupsi Pengadilan Negeri Jakarta Pusat menggelar sidang perdana pembacaan dakwaan perkara korupsi pengadaan KTPel dengan terdakwa Setya Novanto pada Rabu (13/12) walaupun sempat diskors tiga kali (072/REP/17/12/17)

(2) Istri Setya Novanto Sebut Suaminya dalam Kondisi Sehat (076/KOM/17/12/17)
Dalam perkara ini Novanto didakwa menerima 7,3 juta dolar AS dan jam tangan Richard Mille senilai 135 ribu dolar AS dari proyek KTP-el. Setya Novanto menerima uang tersebut melalui mantan direktur PT Murakabi sekaligus keponakannya Irvanto Hendra Pambudi Cahyo maupun rekan Setnov dan juga pemilik OEM Investmen Pte.LTd dan Delta Energy Pte.Lte yang berada di Singapura Made Oka Masagung (088/MI/17/12/17).

Sementara itu, perbedaan penyebutan nama pelaku terdapat pada Republika. Media ini menyebutkan nama pelaku dengan sebutan yang lain, yaitu 1) Setnov, 2) Babeh Asiong, 3) SN, dan 4) S. Istilah Setnov untuk menyebutkan nama pelaku ini menjadi ciri khas Republika. 
(3) Ditanya Kondisi Setnov, Istri Alhamdulillah (070/REP/17/12/17) \

(4) Adapun, Babeh Asiong yang dimaksud adalah Setya Novanto. Dalam perkara ini Novanto diduga menerima 7,3 juta dollar AS dan jam tangan Richard Mille senilai 135 ribu dollar AS dari proyek KTP-el (115/REP/22/02/18)

(5) KPK menetapkan saudara SNanggota $D P R$ RI pada 2009 sampai 2011 sebagai tersangka. Karena menguntungkan diri sendiri menyebabkan kerugian negara Rp2,3 triliun dari paket pengadaan Rp5,9 triliun (003/REP/17/07/17)

(6) "Ada kalimat jatah si Asiong ada di S. Jelaskan?" Tanya Jaksa KPK Abdul Nasir" (113/REP/22/02/18)

Lain halnya dengan Kompas dan Media Indonesia tidak pernah menyebutkan nama pelaku dengan sebutan Setnov. Selain sebutan Setnov, Republika juga menyebutkan pelaku dengan nama samaran, yaitu Babeh Asiong, SN, dan S. Penyebutan nama samaran itu terdapat pada kutipan pembicaraan penyidik KPK dan beberapa saksi. Penyebutan nama samaran atau inisial berhubungan sangat dengan dengan status hukum yang pelaku. Namun, jika status pelaku menjadi tersangka, media tidak harus menuliskan inisial pelaku tersebut. Penulisan inisial dalam pasal 5 kode etik jurnalistik digunakan untuk menyebutkan dan menyiarkan identitas korban kejahatan susila dan tidak menyebutkan identitas anak yang menjadi pelaku kejahatan. Dalam kasus ini, Republika lebih lengkap menyebut nama pelaku dibandingkan dengan media lainnya dan media ini mempunyai ciri khas penyebutan nama pelaku, yaitu Setnov. Media lain, seperti Kompas dan Republika tidak pernah menyebut nama pelaku dengan sebutan Setnov. Republika lebih lengkap mengungkap identitas pelaku kasus e-KTP ini dengan menyebutkan namanama lain Setya Novanto. Sama seperti penelitian yang dilakukan oleh Yaghobi (2009) yang menemukan bahwa pilihan bahasa dan paparan dalam berita yang disajikan oleh orang-orang media dan para wartawan hadir berdasarkan dari ideologi yang berbeda, walaupun itu sebuah peristiwa yang sama. Republika memiliki ciri khas yang berbeda dengan media lainnya dalam menyebutkan nama pelaku kasus e-KTP.

Pada bagian atas, terdapat nama samaran yang terungkap oleh Republika untuk nama pelaku, yaitu Babeh Asiong. Nama samaran ini berbeda dengan nama samaran yang lain, seperti SN (Setya Novanto), S (Setya). Nama samaran SN dan S dalam kasus e-KTP sudah sangat jelas mengerucut pada nama Setya Novanto. Sementara itu, penyebutan nama Babeh Asiong sangat berbeda dengan sebutan SN atau S. Tidak semua orang tahu siapa Babeh Asiong. Nama tersebut terungkap ketika Mantan Direktur Utama PT Quadra Solution Anang Sugiana Sudiharjo mengakui adanya pemberian uang sebesar 1,8 juta dollar AS terkait proyek pengadaan KTP Elektronik (KTP-el) kepada Setya Novanto.Pemberian kepada Novanto yang saat itu menjabat ketua Fraksi Partai Golkar di DPR. Analisis adanya dua bentuk nama samaran yang berbeda untuk pelaku kasus e-KTP, yaitu 1) nama samaran digunakan untuk keperluan penyidikan dengan model singkatan, seperti $S N$ dan $S$, 2) nama samaran digunakan untuk keperluan tindak korupsi. Para pelaku tindak korupsi mempunyai kode khusus ketika melakukan tindak korupsi. Terungkapnya nama samaran tersebut menunjukkan adanya penyalahgunaan anggaran memang telah direncanakan. Hal ini terbukti ketika pelaku korupsi e-KTP tidak menggunakan nama mereka yang sebenarnya, tetapi menggunakan nama samaran.

Berdasarkan pemaparan di atas, representasi identitas pelaku yang dilakukan oleh tiga media nasional berbeda. Republika mempunyai ciri khas khusus untuk menyebut nama pelaku, yaitu Setnov. Sementara itu, media lainnya tidak demikian.

Republika juga berhasil merepresentasikan nama samaran yang digunakan oleh pelaku dalam menjalankan kecurangan, yaitu Babeh Asiong. Nama samaran ini bisa menjadi salah satu barang bukti di pengadilan. Dengan demikian, Republika berhasil mengungkap identitas lebih dalam dibandingkan Kompas, dan Media Indonesia. 


\section{Representasi Jabatan Pelaku}

Selain identitas berupa nama pelaku kasus korupsi E-KTP, ketiga media juga menyebutkan jabatan Setya Novanto. Sebelum terjun ke dunia politik Setya Novanto berprofesi sebagai pengusaha.I a memiliki pengalaman selama empat belas tahun menjadi pengusaha. Puncak kariernya ketika ia ditunjuk menjadi Kepala Penjualan mobil untuk seluruh wilayah Indonesia Timur. Awal karier Setya Novanto dalam dunia politik dimulai pada pemilu 1999 , ia terpilih menjadi anggota DPR dari daerah pemilihan Nusa Tenggara Timur (NTT). Pada pemilu berikutnya, ia tiga kali berturut-turut kembali terpilih menjadi anggota DPR. Jabatan di DPR terus menaik, dimulai sebagai anggota, bendahara, hingga ketua Fraksi Partai Golkar. Puncak karier Setya Novanto dalam dunia politik yaitu pada 2 Oktober 2014, ia terpilih menjadi Ketua DPR RI 2014-2019 (Viva, 2018). Berikut ini representasi jabatan pelaku dalam tiga media nasional.

Republika menyebutkan jabatan Setya Novanto sebagai: 1) Mantan Ketua DPR RI, 2) Mantan Ketum Partai Golkar, dan 3) Anggota DPR. Kompas hanya menyebutkan dua jabatan Setya Novanto, yaitu 1) Mantan Ketua DPR RI dan 2) Mantan Ketum Partai Golkar. Sementara itu, Media Indonesia menyebutkan tiga jabatan Setya Novanto, yaitu: 1) Mantan Ketua DPR RI, 2) Mantan Ketum Partai Golkar, 3) Politisi Partai Golkar. Sama halnya seperti hasil penelitian Beti dan Kusno (2017) yang mengatakan bahwa berdasarkan analisis tekstual (analisis mikro) menunjukkan bahwa media ketika menyampaikan beritanya memiliki struktur teks pendek dan langsung menyampaikan isi tuturan. Sama seperti juga dalam penelitian ini, media secara langsung menyebut beberapa jabatan yang pernah dimiliki oleh Setya Novanto.

Ada dua persamaan penyebutan jabatan Setya Novanto dalam tiga media tersebut, yaitu Mantan Ketua DPR RI dan Mantan Ketum Partai Golkar. Bukan menjadi rahasia umum lagi bahwa Setya Novanto sebelumnya menjabat sebagai Ketua DPR RI periode 2014-2019.Ia mundur menjadi Ketua DPR RI pada Desember 2017 karena kasus
E-KTP.Sebelumnya, ia juga mundur sebagai Ketua Umum Partai Golkar pada September 2017.

Ketiga media nasional menyebutkan jabatan Setya Novanto sebagai Mantan Ketua DPR RI karena ini jabatan tertinggi karier politik Setya Novanto. Selain menyebutkan jabatan Ketua DPR RI, ketiga media nasional tersebut juga menyebutkan jabatan Setya Novanto sebagai Ketua Umum Partai Golkar. Peyebutan jabatan yang kedua ini tentu ada alasan politis di dalamnya. Berdasarkan penyebutan jabatan tersebut, mengandung informasi bahwa pilihan politik Setya Novanto berada pada partai yang berlambangkan pohon beringin. Posisi terakhir beliau di partai ini sebagai Ketua Umum.

Penyebutan jabatan Mantan Ketua Umum Partai Golkar pada kasus e-KTP yang melibatkan Setya Novanto ini tentunya mempengaruhi kredibilitas Partai Golkar di masyarakat. Ketiga media nasional tidak mau menutup-nutupi jabatan Setya Novanto di partai tersebut. Hal ini terjadi terkait dengan pilihan politik ketiga media tersebut yang berbeda dengan pelaku sehingga tanpa tedeng alingaling ketiga media tersebut menyebut partai pengusung pelaku kasus e-KTP tersebut.

Terdapat juga perbedaan antara Republika, Kompas, dan Media Indonesia dalam penyebutan nama jabatan. Satu-satunya media yang menyebutkan Setya Novanto sebagai anggota DPR hanya Republika. Media ini ingin menunjukkan bahwa keterlibatan Setya Novanto pada kasus e-KTP ketika ia menjabat sebagai anggota DPR.

Setya Novanto tercatatmenjadianggota DPR RI periode 2009-2014. Republika ingin menunjukkan bahwa Setya Novanto terlibat korupsi e-KTP sebelum ia menjabat sebagai ketua DPR RI. Hampir semua jabatan penting yang pernah diduduki oleh pelaku diungkap Republika. Konsentrasi media ini untuk menginformasikan kasus ini secara mendalam memang cukup besar.

\section{Representasi Nama Istri Pelaku}

Identitas lain Setya Novanto yang tercatat dalam ketiga media nasional adalah nama istri beliau. Berikut ini isi berita yang 
menyebutkan istri Setya Novanto. Nama istri Setya Novanto terungkap ketika media memberitakan Setya Novanto tidak bisa menjawab pertanyaan pada saat sidang perdananya. Ia beralasan karena sedang sakit. Republika dan Media Indonesia menulis berita bahwa ketika ditemui awak media seusai menjenguk Novanto, Deisti menyatakan kondisi suaminya dalam keadaan sehat.Ia menyatakan bahwa tidak mengeluh sakit seperti yang diungkapkan saat sidang perdana. Sebelumnya, pengadilan tipikor Pengadilan Negeri Jakarta Pusat menggelar sidang perdana pembacaan dakwaan perkara korupsi pengadaan KTP-el. Pembacaan dakwaan ini sempat diskors tiga kali. Akhirnya, pembacaan dakwaan dilakukan pada pukul 17.10, sedangkan jadwal awalnya pukul 09.00 WIB.

Pada saat sidang perdana, dihadirkan seorang dokter KPK, tiga dokter RSCM, dan satu perwakilan Ikatan Dokter Indonesia (IDI) untukmenyampaikan hasil pemeriksan terhadap Setya Novanto tidak mampu menyampaikan identitas dirinya. Penasihat Hukum juga sudah menghadirkan dokter dari RSPAD pada jeda pukul 11.30 WIB, namun Novanto menolak diperiksa dengan alasan dokter tersebut adalah dokter umum, bukan dokter spesialis.

Kedua media tersebut (Republika dan Media Indonesia) mendeskripsikan kejadian sidang perdana Setya Novanto secara jelas. Hal tersebut berbeda dengan Kompas yang hanya memberitakan tentang keadaan Setya Novanto. Kompas tidak menuliskan kronologi secara detail mengenai kejadian di saat sidang perdana kasus E-KTP. Hanya saja Kompaslebih lengkap ketika menyebutkan nama istri Setya Novanto, yaituDeisti Astriana Tagor.

Selanjutnya, Republika menyebutkan nama istri pertama Setya Novanto pada saat KPK memanggil kedua anak Setya Novanto. Pada saat itu juga, Republika menyebut nama istri pertama Setya Novanto, Luciana Lily Herliyanti. Sementara itu, Kompas dan Media Indonesia tidak menuliskan nama istri pertama Setya Novanto. Bahkan Media Indonesiat idak memuat berita tersebut.

Berdasarkan pemaparan berita mengenai keadaan Setya Novanto pada saat sidang pertama, Republika dan Media Indonesia begitu detail menuliskan kejadian tersebut. Hal tersebut berbeda dengan Kompas. Walaupun topik berita pada hari tersebut sama, Kompas tidak menyebutkan siapa istri pertama dan kedua Setya Novanto. Republika menyajikan segala informasi mengenai Setya Novanto lebih lengkap dibandingkan Kompas dan Media Indonesia.

\section{Representasi Nama Anak dan Keponakan Pelaku}

Identitas berikutnya yang terungkap adalah nama anak dan keponakan Setya Novanto. Munculnya kedua nama anak Setya Novanto dan dalam kasus e-KTP ketika KPK meminta keterangan mereka berdua terkait pengadaan penerapan e-KTP. Sementara itu, keponakan Setya Novanto diduga terlibat dalam kasus ini.

Republika, Kompas, dan Media Indonesia menyebut nama putra Setya Novanto terkait kasus ini. Putra Setya Novanto, Reza Herwindo, memiliki saham di PT Mondialindo, selain istri Novanto, Deisti Astriani Tagor. Sementara itu, saham PT Murakabi dimiliki putri Novanto, Dwina Michaella, dan keponakan Novanto, Irvanto Hendra Pambudi. Kantor kedua perusaahaan besar ini berada dalam satu lokasi yang sama, yaitu di gedung Menara Imperium lantai 27. Pemilik kedua kantortersebut adalah Setya Novanto.

Tim penyidik kasus e-KTP ini secara berkesinambungan memanggil saksi-saksi kunci keterlibatan Setya Novanto dalam kasus korupsi mega proyek nasional ini.KPK menduga keluarga Setya Novanto terlibat kasus ini. Hal ini terungkap oleh tim penyidik terkait dasar bukti berupa akta notaris yang menyebut mereka sempat memegang saham PT Mondialindo Graha Perdana. Keikutsertaan PT Murakabi dalam tender e-KTP pada 2011 diduga sebagai bagian rekayasa tender yang telah diatur untuk memenangi konsorsium Percetakan Negara Republik Indonesia (PNRI).Perlu diketahui bahwa perusahaan ini merupakan pemilik saham mayoritas PT Murakabi Sejahtera yang kemudian sempat mengikuti lelang proyek e-KTP, namun pada akhinya kalah dari konsorsium PNRI. 
Nama keponakan Setya Novanto, Irvanto Hendra Pambudi muncul di Republikadan Kompas. Sementara itu, Media Indonesia tidak menyebutkan nama tersebut. Keponakan Setya Novanto diduga terlibat proses pengadaan e-KTP dengan perusahaannya, yaitu PT Murakabi Sejahtera. Ia juga beberapa kali mengikuti pertemuan di ruko Fatmawati bersama tim penyedia barang proyek e-KTP (Tempo, 2018).

\section{Representasi Agama Pelaku}

Tidak hanya nama, jabatan, istri, anak dan keponakan, agama pelaku juga tidak luput menjadi sorotan awak media.

Penggambaran agama pelaku menjadi sorotan media pada saat istrinya, Deisti menjenguk suaminya. Pada saat sidang perdana, Setya Novanto tidak dapat menjawab beberapa pertanyaan karena menurutnya ia sedang sakit. Mendengar keaadaan tersebut, Deisti kemudian menjenguk suaminya. Agama pelaku diketahui ketika Deisti mengucapkan kata alhamdulillah untuk menerangkan bahwa keadaan suaminya dalam keadaan baik.Kata alhamdulillah merupakan kata yang diucapkan oleh umat Islam untuk menyatakan rasa syukur karena menerima karunia dari Allah.

Republika dan Media Indonesia tidak mau menutupi apa agama pelaku dan istrinya. Republika dengan latar belakang media Islam ingin menunjukkan ketidakberpihakannya terhadap kasus Setya Novanto. Hal ini terlihat bahwa media ini menyoroti semua yang terkait dengan Setya Novanto, mulai dari nama pelaku, jabatan, agama, istri, anak dan keponakan semua dipaparkan secara jelas. Sementara itu, Media Indonesia lebih fokus menyoroti hal-hal lain tentang Setya Novanto, tanpa menyinggung identitasnya secara lengkap.

\section{SIMPULAN}

Representasi identitas tokoh pelaku kasus e-KTP, Setya Novanto, disajikan dengan cara yang bermacam-macam. Republika cenderung lebih detail dan lengkap dalam merepresentasikan identitas pelaku kasus e-KTP. Selain identitas pelaku utama kasus e-KTP terdapat juga nama lain yang terekam oleh Republika, Kompas, dan Media Indonesia. Penggambaranidentitasdimulaidaripenyebutan nama pelaku, jabatan, istri, anak, keponakan, dan agama. Semua hal yang berhubungan dengan pelaku direpresentasikan pemberitaan kasus ini. Kompas lebih menekankan pada fakta-fakta yang berhubungan dengan pelaku. Tidak semua hal yang berhubungan dengan pelaku terungkap. Sementara itu, Media Indonesia lebih fokus pada keterlibatan aktor lain dalam kasus e-KTP ini.

\section{DAFTAR PUSTAKA}

Brown, G. dan Yule, G. (1983). Discourse Analysis. Cambridge: Cambridge University Press.

Fairclough, N. (1992). Discourse and Social Change.Cambridge: Polity Press.

Mardikantoro, H. B. dan B. Wahyudi Joko S. (2017). Korupsi dalam Konstruksi Media: Analisis Tekstual dalam Pemberitaan Korupsi di Televisi Nasional Swasta Indonesia dalam Perspektif Analisis Wacana Kritis van Djik." PIBSI XXXIV. Semarang, 7-9 November 2017.

Kusno, A. dan Nur B. 2017. "Analisis Wacana Kritis Cuitan Fahri Hamzah (Fh) Terkait Hak Angket Komisi Pemberantasan Korupsi (KPK)." Ranah: Jurnal Kajian Bahasa. Vol 6 (2), 2017, halaman 137-157.

Setiawan, T. 2014. Ancangan Awal Praktik Analisis Wacana Kritis: Jurnal Ilmiah DIKSI. Vol 2 no. 22, September 2014, halaman 111-120.

Sobur, A. 2004. Analisis Teks Media. Bandung: Rosda Karya.

Shoemaker, P. J dan Reese, S. D. 1996. Mediating The Message, Theories of Influenceson Mass Media Content. New York: Longman Publishers USA.

Tempo, 2018. "Begini Peran Keponakan Setya Novanto dalam Kasus Korupsi E-KTP." Diunduh pada 17 Juli 2018 dari https:// nasional.tempo.co/read/1065418/ begini-peran-keponakan-setyanovanto-dalam-kasus-korupsi-e-ktp. 
Viva. 2018. "Profil Setya Novanto." Diunduh pada tanggal 6 Juli 2016 dari http:// www.viva.co.id.
Yaghoobi, M. 2009. "A Critical Discorse Analysis of the Selected Iranian and American Printed Media on the Representation of HizbullahIsrael War. Jurnal of Intercurtural Communication. No. 21, 2019. 